\begin{tabular}{r} 
Research Article \\
(C) 2022 Anselm Adodo. \\
\hline P U B I I S H I II G \\
This is an open access article licensed under the Creative Commons \\
Attribution-NonCommercial 4.o International License \\
(https://creativecommons.org/licenses/by-nc/4.0/)
\end{tabular}

Received: 17 November 2021 / Accepted: 30 December 2021 / Published: 5 January 2022

\title{
A Political Economy of Wellbeing/Wellness in Nigeria
}

\author{
Anselm Adodo \\ Research Associate, \\ University of Johannesburg, \\ South Africa
}

DOI: https://doi.org/10.36941/mjss-2022-ooo1

\begin{abstract}
Since the turn of the new millennium, which was the period of clear comparison and computation of the misery index, Nigeria had always record low in the index for the report. Within the last three years, the misery index that was published has shown that Nigeria is the sixth (6th) most miserable country that one can reside. This measure of misery index was also substantiated by the recent report from the World Bank on the issue of poverty, inequality, and wellness. However, it seems to be an intensified interest in how Nigeria will overcome such an unpleasant pattern. In this research, the study examined how macroeconomic indices in enhancing people's wellbeing-utilising economic growth, monetary policy position, and governance efficiency as, unemployment, interest rate, and inflation rate for macroeconomic performance indicators. The conclusions drawn suggest that economic growth, resulting in the advancement of wellbeing via allocative as well as distributive productivity is possible. Second, there is a stiffening effect on the wellbeing of contractionary monetary policy which increases interest rates and unemployment rates. The outcome extracted also shows that unnecessary domestic lending characteristics of the Nigerian economic system invalidate the wellbeing of the Nigerian people. Therefore, it proposed that the monetary authority reevaluate its present position on sustaining a high level of rediscount rate.
\end{abstract}

Keyword: wellbeing/wellness, misery, economic growth

\section{Introduction}

Governments around the globe (either a socialist government or a capitalist government) are obsessed with their citizen' wellbeing. Intrinsically, state initiatives targeted at enhancing macroeconomic sustainability inevitably tend to strengthen the economy and its citizens' welfare (Okonji \& Igbanugo, 2019). Nevertheless, as noted by Dynan \& Sheiner (2018), it is more challenging to quantify an individual's wellbeing development as compared to that of a nation. Economic indicators, including GDP as well as other national wealth indices, could be utilised to determine financial wellbeing, with next to no dispute. There is controversy, interestingly, as to how to evaluate personal economic wellness.

A variety of controversial indicators of health were established in economic literature. One such metric, established by Veenhoven (2004), is the "livability index." Livability is not a value of individuals, but then of ecosystems or populations, as shown by Veenhoven (2004), and therefore describes the degree that these provide for the fulfilment of human demands and as such their wellbeing. Other wellbeing metrics are premised on the economic climate or resources employs 
GDP per person, viable employment, education, and life expectancy. An excellent illustration of this would be the 1990 developed Human Development Index (HDI) of UNDP. It was conceived to switch the development discussion from an emphasis on GDP to people-centric metrics (Okonji \& Igbanugo, 2019). Another form of measure includes "use of work in capability theory" by Sen (1993) and Nussbaum (2005). Capability measurements highlight that personal wellbeing depends on developing massive social potentials, including the ability to read, feed on oneself, as well as engage in political operations.

Several nations have recently begun to utilise the indexes of happiness to measure the success of government policies. For instance, counties which including Bhutan, Australia, Canada, France, and the United Kingdom employ advanced survey to calculate the metric of gross national happiness $(\mathrm{GNH})$ that also quantifies the standard of the wellbeing of the populace. GNH critics posit that such surveys may be manipulated by governments. It is also contended that such contextual surveys could well complicate global wellness comparisons (Fox, 2012)Another critique of so many happiness metrics is that they hardly reflect the effect on the personal wellbeing of major economic measures of regional economic wellbeing. This makes the comparison between national social prosperity and personal wellbeing challenging(Mansi, Gagan, \& Mandeep, 2019).

To correctly employ macroeconomic metrics to estimate personal economic wellbeing, in 1966, Professor Arthur Okun developed the metric of misery or economic distress. Prof. Arthur developed the index of suffering from calculating how socially humans are progressing. Throughout the 1970s, the index called Okun misery index, which was a combined total of unemployment and inflation was popularised (Okonji \& Igbanugo, 2019). The scheduling of the Introduction was never unforeseen: high inflation and unemployment occurred within the period, in the United States as well as, several parts of the world. Okun misery indicator was traditionally applied to the US (Nessen, 2008).

There are limited studies on how the political-economic situation influences economic wellbeing utilising the index of misery as a primary component of wellbeing. Even though (Di Tella, MacCulloch, \& Oswald, 2001) has berated the misery index for allocating equal value to unemployment (which they assume influences happiness much more inflation) and inflation, it does have characteristics of offering a glimpse of people's level of wellbeing. For instance, several nations that topped the 2017 and 2018 Hanke Misery Index are the world's poorest countries. As social wellbeing in Nigeria has begun to worsen as well as the index of misery kept rising (The misery index rankings release in 2019 shows that Nigeria is ranked $6^{\text {th }}$ most miserable nation all over the world), it is pragmatic to analyse the effect of political and economic efficiency on Nigerians economic wellbeing (Katie, 2019). It is on this note that the current study will analyse the wellbeing/wellness of Nigerians given the economic performance over the years.

\section{Nigeria's Microeconomic Performance: Stylised Facts}

\subsection{Economic Growth}

During the last three decades, Nigerian macroeconomy has undergone considerable fluctuations. It seemed to have its slice of the economic cycle boom as well as burst context (Alege, 2009). For instance, between the years 1967 and 1978, the growth of Nigeria's economy was on an average of $4.23 \%$, this was a result of the favourable high price of crude (Okonji \& Igbanugo, 2019). The trend of the increase in price for crude oil was from $\$ 2 \mathrm{pb}$ in the year 1973 to $\$ 14.33 \mathrm{pb}$ in the year 1978 . By the year 1979, the price of crude oil has risen to $\# 29.27 \mathrm{pb}$ all through to the year 1980 when the price of crude oil rose to $\$ 37 \mathrm{pb}$. The increase got to the peak in the year 1981 when crude oil was sold at $\$ 40 p b$ after which the crude oil market suffered a huge crash (Baumeister \& Kilian, 2016). The escalating prices of crude oil were predominantly influenced by the 1973-75 Arab-Israeli war, within the period, the growth rate of the economy was very high at $14 \%$ in the year 1971, $11.2 \%$ in the year 1974 and attained a growth rate of $6.8 \%$ in the year 1979. However, the decline in the growth of the Nigerian economy that started in the year 1981 was as a result of the oil glut witnessed in the oil market. 


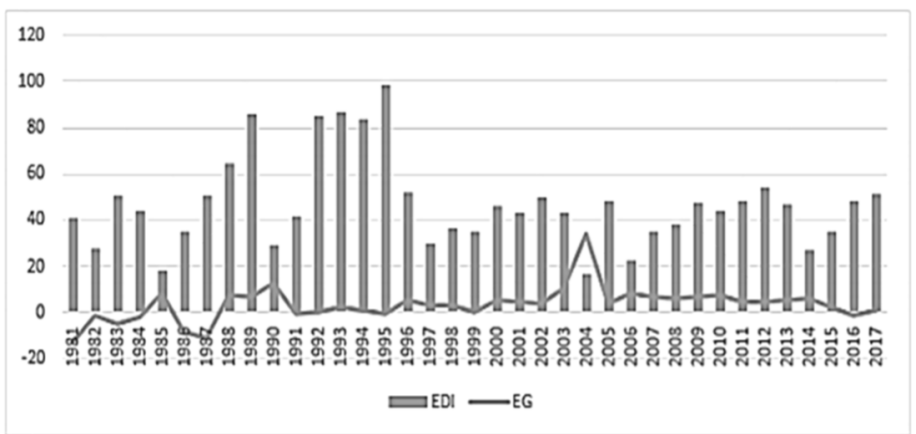

Figure 1: Pattern of Economic Discomfort Index (Misery) and Economic Growth

From the figure above, it could be seen that in the year 1981, the economy crashed into a recession which continued all through to the years 1987 , although the economy had positive growth in 1985 . As stated earlier that the decline in growth was as a result of the influx of the supply of crude oil which resulted to a glut in the crude oil market and a drop in the revenue of the government of Nigeria, the crash was so much that oil was sold at $\$ 10 p b$ in 1985 . The foregoing situation and the reduction in the production share by OPEC of member countries are part of the rationale for the economic crisis witnessed in the 1980s. Initially, the crude oil production share allocated to Nigeria by OPEC in the 1970 s was 2.3million bpd. However, this was decreased to 1.3million bpd at the start of the 1980s. The figure above also revealed that the misery trend was very high within such period, as could be seen that the misery index rose from 41 in the year 1981 to 50 in the year 1983 and subsequently got to 85 by the year 1989 (Okonji \& Igbanugo, 2019).

Nevertheless, in the year 1985, which was the year the economy recorded some level of positive growth, the index measure dropped to 18.4. However, the economy began to witness some positives in the year 1988, when the Nigerian economy recorded a growth rate of $7.5 \%$ (Okonji \& Igbanugo, 2019). Akinkunmi (2017) stated that the boom which was witnessed towards the end of the 1980 as a result of the structural adjustment programme which was initiated by the government as part of the criteria for the loan from the international monetary fund. The economic boom continued into the year 1990 when the economy witnessed a growth rate of 12.85 as can be seen in the figure above that the misery index was 28.98. By the year 1991, the Nigerian economy witnessed another downturn as the country slumped into recession with a growth rate of $-0.61 \%$. The recession trend continued all through to the year 1995 when the economy had a growth rate of -0.3\%. Within this period in which the economy was retarding, the misery index rose again as it recorded an all-time high figure of 98.07 in the year 1995 from the initial 28.98 recorded in the year 1991. The growth rate of the Nigerian economy has been a little stabilised recording an average growth of 6.8\% between 1996 and 2014 (Okonji \& Igbanugo, 2019).

Akinkunmi (2017) argued that the stability witnessed in the growth of the Nigeria economy between the end of 1990 s up to 2014 is as a result of a consistent governance approach that has witnessed the return to democratic rule, one may as well argue that the consistency in the price of oil over the period could have contributed to the growth rate experienced within the economy. The economic events of the 2015 and 2016 could be a pointer to this claim, as crude oil price witnessed a significant decline in 2015 , leading to a decline in the growth rate of the economy from $6.3 \%$ in the year 2014 to $2.7 \%$ in the year 2015 and subsequently slumped to $-1.6 \%$ in the year 2016 (Tule, Egbuna, Dada, \& Ebuh, 2017). It should be resounded that Nigeria had its highest growth ever in 2004 when the growth rate hit $33.3 \%$, correspondingly, the misery index witnessed the all-time lowest value at $16.4 \%$. As at the end of 2019 , Nigeria's growth rate was $1.9 \%$ which is likely to be affected by the current coronavirus pandemic popularly called COVID-19, as Nigeria's Gross Domestic Product 
contracted by $14.3 \%$ (Trending Economics, 2020). The misery index within this period is 53.3, making Nigeria the $6^{\text {th }}$ most miserable country in the world (Katie, 2019). One can conclude that a high misery rate is a function of a low growth rate which subsequently affects the social and political wellbeing of the masses.

\subsection{Unemployment, Inflation and Lending Rate}

The Government of Nigeria has overtime formulated several policies that aim to create employment opportunities, thereby maximise unemployment and enhance the wellbeing of Nigerian citizens. Some of such policies of government include; Operation Feed the Nation (OFN) instituted by the then military head of state General Olusegun Obasanjo in 1976, the Directorate of Food, Road and Rural Infrastructure (DIFRRI) was introduced by another military head of state, General Ibrahim Babangida in the year 1986, this employment to individuals interested to go into agriculture. The same military government of General Ibrahim Babangida in November 1986 established National Directorate of Employment (NDE) which kick-started in January 1987. The program was saddled with the responsibility of training several unemployed individuals in one skill or the other so that they can start theirs. The government went further to initiate funding programs to provide financial assistance for small businesses (Okonji \& Igbanugo, 2019).

The Federal Government under Goodluck Jonathan in 2011, launched a programme called YouWin, which was a programme aimed at the development of youth via the financing of the business plan of entrepreneurs that sounds good and outstanding. Odiji, Nwoke, \& Adeseke (2016) stated that the programme had empowered approximately 4000 Nigerian youth before it was terminated in 2015 .

The major issue regarding unemployment is that aside from deteriorating the misery of an individual, it also has an undesirable spillover influence on the economy as well as the society, respectively. This results in loss of output, thus exacerbating the cyclical economic situations. It is also fueling social unrest. In reality, the increasing problem of insecurity in Nigeria (which manifests itself in banditry, kidnapping/abduction, militancy including terrorism) was connected to the increased unemployment rate prevalent within the country (Garver, 2020). In Nigeria, the management of inflation continued to remain a significant priority of the CBN. This is as well since the rate of inflation has lingered pretty much entirely in double-digit since the 1990s (Bamidele, 2019).

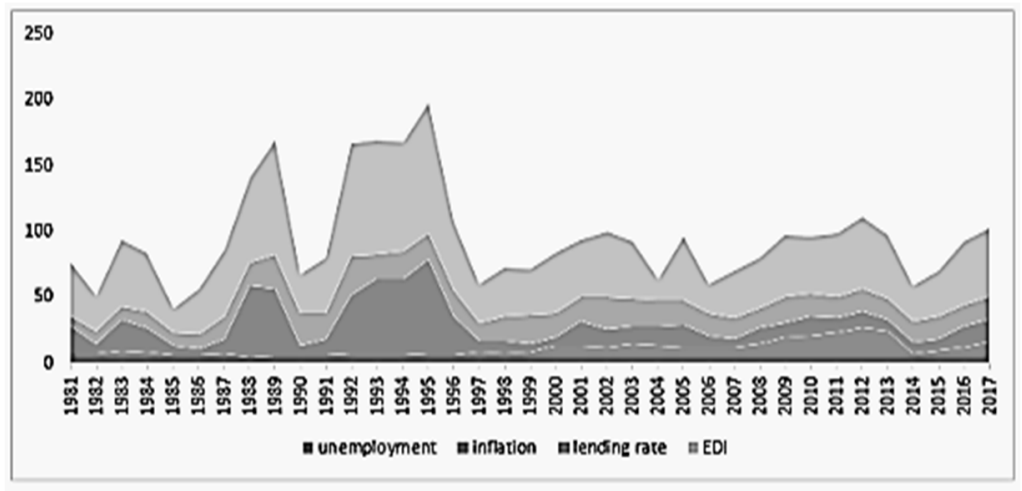

Figure 2: Trend of unemployment, Inflation, Lending Rate and Economic Discomfort Index (Misery)

The worst experience of inflation in Nigeria was in the year 1995, the year when Nigeria had an inflation rate of $72.8 \%$. Though the inflation rate between 1985 to 1990 as on the average of $7.4 \%$ in 1996 the inflation rate was well over $57 \%$. Since the rate of inflation in the country has continued to fluctuate, and affect the disposable income of individuals hence, leaving them with little cash to spend. As the standard of 
living becomes unaffordable. By the year 2000, the inflation rate had dropped to as low as $6.9 \%$, by 2005 inflation rate rose to $17.9 \%$, there was a decline in the year 2010 to $13.7 \%$, and further decline to $10.8 \%$ in the year 2011. In 2012, there was a slight increase in the inflation rate to $12.2 \%$, declined to $8.5 \%$ in 2013 , and further decline to $8.1 \%$ in the year 2014. The decline was never sustained as the country recorded an inflation rate of $9.0 \%$ in 2015 and further increase to $18.6 \%$ in the year 2016 , by 2017 there was an inflation rate of $15.4 \%$. The inflation rate declined to $12.09 \%$ and $11.4 \%$ respectively in the year 2018 and 2019 . As of the first quarter of 2020 inflation rate had increased to $13.39 \%$ (Statista, 2020).

\begin{tabular}{llll}
\hline Years & Actual & Target & $\begin{array}{l}\text { Differential } \\
(\%)\end{array}$ \\
\hline 1990 & 3.6 & $*$ & \\
1995 & 51.6 & 15.00 & 243.94 \\
2000 & 14.5 & 9.0 & 61.41 \\
2005 & 11.6 & 10.0 & 15.65 \\
2010 & 11.8 & 11.2 & 5.36 \\
2011 & 10.3 & 12.0 & -14.31 \\
2012 & 12.0 & 9.5 & 26.12 \\
2013 & 7.96 & 9.87 & -19.38 \\
2014 & 7.98 & 7.50. & 6.38 \\
2015 & 9.55 & 8.00 & 19.38 \\
2016 & 18.55 & 11.90 & 55.88 \\
2017 & 15.37 & 10.71 & 43.53 \\
\hline
\end{tabular}

Source: Central Bank of Nigeria (2017)

Looking at the table above, it is obvious that consistently Nigeria has always set a low target for the inflation rate, close observation of the table shows that Nigeria in the past two decades met the inflation target only in 2011 and in 2013 the years where the actual inflation rate appears to be lesser than the target.

Obi \& Akubuo (2018) acknowledged that the Central Bank Nigeria's Monetary Policy Committee ( MPC) has been much more interested in the rate of inflation than with the rate of unemployment. Indeed, the MPC seems to have been monetary hawks, rather than doves. Even during the period recession, the Monetary Policy Committee persisted in maintaining a high bank rate, commonly called in Nigeria as the monetary policy rate. Increasing the bank rate seems to have been attributable to the suspicion that lower bank rates will indeed result in increased money supply as well as increase the rate of inflation (Bloomberg, 2019). An extremely high lending rate is the biggest consequence of a high bank rate. High lending rates in underdeveloped nations could perhaps exacerbate unemployment and inflation. The figure below revealed that appears to be relatively high in the countries that appear to be more miserable compared to countries with less miserable indices. For instance, Venezuela lending, the country that appears to be the most misery nation in the globe, is $24 \%$. This means that Venezuela's lending rate is $452 \%$ higher, unlike China, which seems to be one of the least miserable nations in the world. Argentina, which has a lending rate of $60.2 \%$, appears to be the third miserable nation all over the world. The $6^{\text {th }}$ most miserable country in the world, which is Nigeria have a lending rate of $16.2 \%$ (Okonji \& Igbanugo, 2019). The comparison is shown in the figure below;

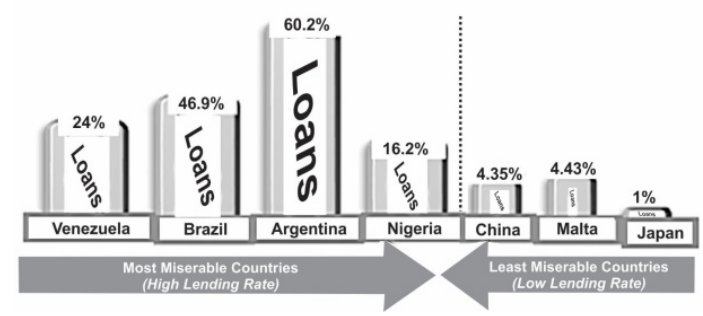

Source: Okonji \& Igbanugo (2019). 
The rationale for the analysis above has been to highlight the prevailing condition within the Nigeria system which appears not to provide a better environment that supports an efficient health system for the good wellbeing and wellness of the Nigerian populace.

\section{Structure of Health Care Funding in Nigeria and Africa}

Health appears to be the first wealth of a nation. Atun \& Fitzpatrick (2015) stated that evidence from the empirical literature has shown that a country's health is synonymous to the development of the economy of such country and vice-versa. Several health issues that include HIV/AIDS, malaria, under- 5 mortality, tuberculosis and maternal mortality have contributed to the lack of growth and improvement witnessed in underdeveloped countries which are predominantly African. However, it has been amplified that attaining a better health system should not be a waiting function of the improvement of the economy. Rather setting in place strategies to enhance the health sector will contribute significantly to the growth of the economy(Alsan, Bloom, \& Canning, 2006) Carrin, Evans, \& Xu (2017)stated that the approach employed in financing the health care system by a country is a fundamental determinant of the state of health of her citizen. Adequate selection of an effective approach of financing as well as the delivery system of the health service institution is necessary for a nation to accomplish the target of the national health care for all (Drouin, 2008).

According to Gottret \& Schieber (2016) and Clark, Fleche, Layard, Powdthavee, \& Ward (2017), the financing system of health care encompasses then measures through which funds are raised, distributed and put into use for the benefit of the health care system. It entails the three crucial function of revenue collection, resource pooling and buying of services. There are several measures for the implementation of these functions, but the most prominent in Nigeria and Africa is the outof-pocket payment other funding means include tax-based financing, donor finding and insurance on health (Gottret \& Schieber, 2016). According to Drechsler \& Jütting (2015), these funding approaches are not mutually exclusive as most health system often goes with a mixed approach of the various methods. In measuring the success rate of the various approaches adopted sever factors are considered which includes health outcomes, equity of access to health care, generation of revenue, the efficiency of the system and the influences of the approach on the providers and the behaviour of the user ((Palmer, Mueller, Gilson, Mills, \& Haines, 2014). From the factors mention, equity of access to health care appears to be an issue in Nigeria due to out-of-pocket funding for funding health care system. This has resulted in the rich being the set of individuals that have access to good health care services. The situation has subsequently restricted the productivity of the poor masses, and such affect the quality of the workforce available in the economy.

The operation of the healthcare services in Nigeria appears to be complex (Babayemi, 2012). It comprises of several health care providers both in the public sector and in the private sector that includes "private for-profit providers, non-governmental organisations, community-based organisation, the religious organisation that provides health care, as well as the traditional health care providers(World Health Organization, 2017).

Nigeria's public health sector appears to be highly decentralised and controlled by the three arms of government that is in these formats; The Federal Ministry of Health (FMOH), the State Ministry of Health (SMOH) and lastly the Local Government Health Department (LGHD). The $\mathrm{FMOH}$ is the body in charge of formulating policies that guide health services within the country. Aside from controlling the health care activities in the country, it provides health care services through the Federal Medical Centers across the countries and the Federal Teaching Hospitals. The SMOHs is limited to providing secondary health care services through the Hospitals owned and controlled by the state while the LGHDs are saddled with the responsibility of providing primary health care services (PHC), this is done through the primary health centres in various communities. Though managing the PHC is within the purview of the LG, the three levels of government and several other agencies also participate in the operations of the primary health care. This constitutes the overlap in functions, duplication of functions and also confusion/conflict of responsibilities and 
roles in Nigeria(World Bank, 2015).

Funding for health care services in Nigeria and most of Africa remain a function of revenue form tax, out-of-pocket payment, funds from donors as well as health insurance scheme(World Health Organization, 2017) According to Soyinbo (2015), the budget allocation to the health sector in Nigeria appears to be relatively low especially when compared to other countries in Africa. The trend of the expenditure on health as a ratio of gross domestic product Nigeria and some African countries from 2016 to 2018 are shown in the chart below:

HEALTH EXPENDITURE AS A \% OF GDP

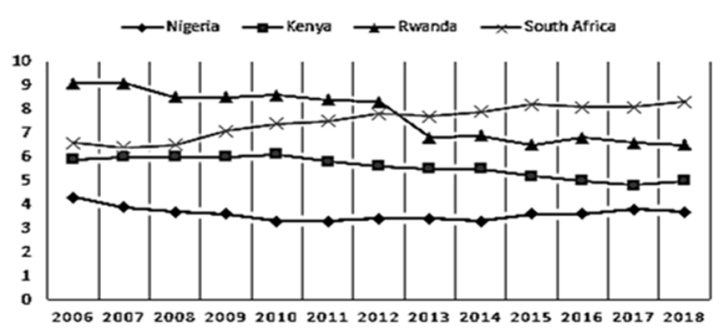

Source: World Data Atlas (2020)

Looking at the trend of the expenditure on health in the chart above, compared to that of some African countries, one would then comprehend why accomplishing an efficient health care financing system has remained a big challenge to Nigeria. Adinma \& Adinma (2017) attributed the above scenario to corruption, limited capacity of health institutions, erratic economic cycle and also the political system. Furthermore, some health care financing mechanism is also not effective.

\section{Out-of-Pocket Financing of Health Care Services in Nigeria}

This is the approach of health care financing in which the receiver of the service pay at the point of service. The user fees have a scope that varies and includes costs for the combination of drugs, the cost for medical materials, consultation fees, entrance fee and many more (Lagarde \& Palmer, 2016). Soyinbo (2015) amplified the issue of out-of-pocket accounting for the largest proportion of expenditure on health in Nigeria. Between 1998 to 2003, 64.59\% of the Nigeria population fund their health care service through the out-of-pocket, in 2003 it rose to $74 \%$ and dropped to $66 \%$ in 2004, rose again to $68 \%$ in 2005 (Soyibo, Olaniyan, \& Lawanson, 2009). Aregbeshola \& Khan, (2018)they noted that $90 \%$ of Nigerians fund their health services from out-of-pocket financing approach, which led to $0.8 \%$ of the raise in poverty headcount. The implication of this is that household bears the largest part of the burden of expenditure on health in Nigeria. This, however, reduces the disposable income of the household.

Nigeria government introduced that user fee in 1988 under the initiative of Bamako who opined for the sharing of cost as well as the participation od community to enhance the quality and efficiency of health care (Rashad \& Sharaf, 2015). The proposition was that user fee would lead to the availability of health care resources and as well as enhance efficiency and access equality (Masiye, Kaonga, \& Kirigia, 2016). However, the proposition was never accomplished going by the available evidence from the trend of events over time.

Scholars have been attracted by the issue of user fees in Nigeria; nevertheless, there is a paucity of details on the influence of user fees on generating revenue, behaviour seeking medical care, access to care, effectiveness, and service utilisation in Nigeria. Ogunbekun, Adeyi, Wouters, \& Morrow (2006)claimed that user fees would mean a lower usage of health care services without corresponding noticeable quality improvements. It must be observed, nevertheless, that the "willingness to pay does 
not turn into ability to pay". The ability to pay may entail poor households undermining their economic wellbeing in the longer term. It is called disastrous spending on health, and it has shown to be large in Nigeria. It has also been proposed that waivers and or concessions be utilised in Nigeria, but the application of waiver and reservation is plagued with problems that have rendered it unsuccessful in several areas (Babayemi, 2012)

\section{Functionalist Approach to the Political Economy of Well-being}

The functionalist framework to health and disease considers social relationships within the healthcare system as a function of a consensualist society whereby individuals take up a certain delineated duty and executing certain functions which are established social balance and stability. It is important in the systems through which health care providers and other healthcare professionals execute their daily medical work, and also how patients deal with sickness and disease. The famous functionalist framework is to visualise sickness as a probable state of social 'deviance;' that is, the inability to comply in certain situation to social standards and expectations (Lupton, 2011).

Sickness is known to be a pathological disease of the human body that induces either physical as well as social disability and must, therefore, be mitigated as soon as possible. Functionalist theorists contend that many diseases are accompanied by emotions of stereotype, embarrassment and susceptibility. The function of the health care system, therefore, is to act as a fundamental institution of social control, or as a moral guardian of society, employing its capability to differentiate between a normal state of affairs and 'deviance' as the Church as an institution once did. Maintaining social order is, therefore, the foundation of functionalist postulating about the forms of the health problem as well as the medical experience, with medicine being seen as an effective tool for regulating the inherently destructive nature of the disease(Lupton, 2011).

\section{National Primary Health Care Development Fund}

PHC is the foundation pillar of the health system in Nigeria. Nevertheless, it has remained a total mess over the past decades, with its miserable condition having a significant effect on the aggregate productivity of the health system. One of the issues on PHC in Nigeria has been highly labelled as inadequate financing. Accordingly, resolving the persistent underfunding, that has suppressed PHC is prominent on the policy initiative as the NPHCDF introduced in the recently passed national health bill(Reid, 2013).

NPHCDF seems to be a pool of funding to allocate for primary healthcare, with guidance on how to distribute the funds. The fund seeks to pool policy, foreign investor as well as private sector capital. The budget will be provided for the procurement of a minimum basic package for the health services via the NHIS (50\%); the procurement of necessary medicines for primary health care (25\%); the procurement and management of hospitals, infrastructure and transportation (15\%); and the advancement of primary health care human resources (10\%)(Federal Republic of Nigeria, 2008). The NPHCDA will allocate the fund via state primary health care commissions for allocation to local government health officials on the justification of dedication and compliance to the legislation creating the development fund(Federal Republic of Nigeria, 2008). The fund so generated is believed might help enhance the partnership between the private and private sector towards the provision of finance for the health care services in Nigeria.

\section{Concept of Well-Being}

The advancement of the economic wellbeing principle could perhaps be attributed to Adam Smith in economic literature. Adam Smith acknowledges in his Wealth of Nations that individuals interact in economic operations for the sake of being exclusively self-reliant and not about the betterment of the public. However, while pursuing everyone's self-interest, they unknowingly promote society's interest 
(Evensky, 2011). The neoclassical, as well as welfare economy, emerged after Adam Smith promoted the principle of economic wellbeing by utility theory.

As opined by Lykken \& Tellegen (1996), the neoclassical economics was inspired by utilitarianism, and the philosophy of the 18th and 19th centuries spearheaded by Jeremy Bentham and John Stuart Mill, in which happiness is conceived as usefulness, a numerical indicator of pleasure or satisfaction, but which proposes that those very activities or actions which optimise relevance should be initiated. Early neoclassical economists postulated a fundamental metric of utility.

The Introduction of ordinal utilitarianism, which also contended that happiness or desires could only be ranked and not quantified, brought up many arguments about whether economic models can deliver comprehension of wellbeing or wellness phenomena (Okonji \& Igbanugo, 2019). According to Frey \& Stutzer (2002), who mentioned that the neoclassical principle of utility is primarily often used to clarify economic systems and therefore not inherently a normative assumption; prescribing how everyone should operate. Cooter \& Rappoport (1984), nonetheless, had observed previously that the normative assumption of wellbeing is exclusively in the welfare economic framework. Among many others, Pareto (1909), Lerner (1944)Bergson (1938), Arrow (1951) suggested different criteria for evaluating the development of welfare in an economy. The welfare principle is commonly implemented in the evaluation of economic strategies aimed at enhancing social welfare by creating results that optimise overall utility.

Economics of welfare and social welfare is the general welfare of the social environment under welfare economics, which is a function of the social wellbeing or wellness of all people within the social system. Economic wellbeing theory took another turn throughout the late 2 oth century with Happiness Economics sprout forth. The argument that resulted in the momentum began in 1974 with both the journals of Easterlin (1974) and with Scitovsky (1976).

Based on surveys, Easterlin (1974) revealed that individuals in high-income nations were not considerably happier than those in low-income countries. He further acknowledged that increasing earnings throughout nations beyond a specific level did not appear to produce substantial improvements in happiness. Scitovsky (1976), further proposed against the assumption of utility proponents, arguing that individual desires of individuals in capitalist market economies will not automatically produce happiness for themselves and that more resources, income, and consumer goods did not exactly produce more happiness for them. It is contended in Happiness Economics also that measure of economic operation resides in its participation in individual happiness. To put it another way, the end of economic systems is human economic wellbeing. Accordingly, the central goal of the economic investigation is to comprehend how macroeconomic variables such as wealth, jobs, unemployment, and social security, and also social and also institutional variables such as good governance, democracy, and associations influence human wellbeing.

Several economists ended up going even further, as observed by Frey \& Stutzer (2002), to concede that happiness is becoming the new metric of economics, modifying monetary value or ordinary usefulness as the values that economics effectively improves. The aim of economic and public policies in this regard should not be to maximise GDP but to maximise gross national happiness, as calculated by some index of happiness. While economic wellbeing assumptions were already developing, there is sometimes any consensus as to how economic wellbeing is measured. Conversely, empirical research on economic wellbeing is constrained.

From the context of subjective wellbeing, Clark, Fleche, Layard, Powdthavee, \& Ward (2017) examined primary indicators of happiness and misery. Utilising survey data mostly from the US, UK, including Indonesia, they concluded that the issues that are important mainly are the personal interactions of people, as well as their mental and also physical wellbeing. This psychological approach to measuring indicators of inter-temporal misery emphasis on the internal psychoemotional climate.

Burchi \& Passacantilli (2013) had stated repeatedly, conversely, that while wellbeing is a multifaceted concept, infusing the economic perception of wellbeing produces an underlying assessment dilemma in itself. Some economists have employed the metrics of misery as a reasonable 
assessment of wellbeing in this context. Welsch (2007) gave justification that European people respect a great deal regarding economic growth, unemployment, and inflation. To put it another way, European citizens' life satisfaction depends on economic growth, unemployment, and macroeconomic stability.

Consequently, Beja (2014) indicated that economic growth in the Philippines doesn't seem to reduce illness in the nation. Dadgar \& Nazari (2018) analysed the effect of economic development and political and economic stability on Iran's indices of misery. They observed, employing a Vector Autoregressive method, that economic growth in Iran seemed to have a negative relationship with the index of misery. Their study also revealed that weak governance in Iran is fostering suffering.

\section{Conclusion}

Sustaining unemployment, ensuring stable prices as well as guaranteeing sustainable growth in the long-term is the key macroeconomic objectives. This is certainly in line with the ultimate policy goal: enhancing people's wellbeing. This study explored the political and economic wellness of people's overall wellbeing. The study concludes that economic activity generates development in wellbeing by capital accumulation and allocation of resources productivity. Second, there is a weakening influence on the wellbeing of contractionary monetary policy which increases interest rates as well as the unemployment rate.

\section{Recommendations}

- The Government of Nigeria must, therefore, concentrate assiduously on economic growth through the restructuring of the various sector such as agriculture, manufacturing and many more, so that the natural resources found in these sectors can be maximised, and also, there is the need to provide the enabling political atmosphere for the economically favorable policies can thrive.

- CBN should reconsider its position on high MPC, as it has proved to be an inadequate strategic decision.

- The government needs to give priority to increasing output by eliminating supply-side hindrances including high loan rates.

\section{References}

Adinma, E., \& Adinma, B. J. (2017). Community based healthcare financing: An untapped option to a more effective healthcare funding in Nigeria. Niger Med J, 51, 95-100.

Akinkunmi, M. A. (2017). Nigeria's economic growth: past, present and determinants. Journal of Economics and Development Studies, 5(2), 31-46.

Alege, P. (2009). A Business Cycle Model for Nigeria. Abuja, Nigeria: A Paper for Presentation at the African Econometric Society Conference.

Alsan, M., Bloom, D. E., \& Canning, D. (2006). The effect of population health on foreign direct investment inflows to low- and middle-income countries. World Dev, 34(6), 13-30.

Aregbeshola, B. S., \& Khan, S. M. (2018). Out-of-Pocket Payments, Catastrophic Health Expenditure and Poverty Among Households in Nigeria 2010. International Journal of Policy and Mangement, 7(9), 798-806.

Arrow, K. J. (1951). Social choice and individual values:Second edition with "Notes on the Theory of Social Choice. New York: John Wiley \& Sons.

Atun, R., \& Fitzpatrick, S. (2015). Advancing Economic Growth: Investing in Health. A summary of the issues discussed at a Chatham House conference held on 22-23 June 2010. Available from: http://www.chathamhouse .org.uk/files/3312_investhealth.pdf.

Babayemi, O. (2012). Public health care financing in Nigeria: Which way forward? Review Article, 6(1), 4-10.

Bamidele, S. (2019). CBN predicts Nigeria's inflation to remain double digit. Stock Select New Letter: Nairametrics.

Baumeister, C., \& Kilian, L. (2016). Forty Years of Oil Price Fluctuations: Why the Price of Oil May Still Surprise Us. Journal of Economic Perspectives, 30(1), 139-160. 
Beja, E. (2014). Yet, two more revisions to the Human Development Index. Forum for Social Economics, 43(1), 2739.

Bergson, A. (1938). A reformulation of certain aspects of welfare economics. Quarterly Journal of Economics, 52, 310-334.

Bloomberg. (2019). A slowdown in the world economy are forcing global policy makers to express fresh caution. https://economictimes.indiatimes.com/markets/stocks/news/caution-is-the-watchword-for-the-worldstop-central-banks/articleshow/67544536.cms.

Burchi, F., \& Passacantilli, A. (2013). Inequality in the monetary and functioning spaces: The case of Peru under the first Garcia Government (1985-1990). Journal of International Development, 25(3), 340-361.

Carrin, G., Evans, D., \& Xu, k. (2017). Designing health financing policy towards universal coverage. Bull World Health Organ [PUBMED], 85, 652.

Central Bank of Nigeria. (2017). Annual Statistical Bulletin. https://www.cbn.gov.ng/documents/Statbulletin.asp.

Clark, A. E., Fleche, S., Layard, R., Powdthavee, N., \& Ward, G. (2017). The Key determinants of happiness and misery. CEP Discussion Paper No 148, June.

Cooter, R., \& Rappoport, P. (1984). Were the ordinalists wrong about welfare economics? Journal of Economic Literature, 22, 507-530.

Dadgar, Y., \& Nazari, R. (2018). The impact of economic growth and good governance on misery index in Iranian economy. European Journal of Law and Economics, 45, 175- 193.

Di Tella, R., MacCulloch, R. J., \& Oswald, A. J. (2001). Preferences over inflation and unemployment: evidence from surveys of happiness. Center for European Integration, 335-341.

Drechsler, D., \& Jütting, J. (2015). Private Health Insurance in Low and Middle-Income Countries: Scope, Limitations, and Policy Responses. Issy-les Moulineaux: OECD Development Centre.

Drouin, A. (2008). Methods of financing health care: A rational use of financing mechanisms to achieve universal coverage. Technical report 05. International Social Security Association.

Dynan, K., \& Sheiner, L. (2018). GDP as a Measure of Economic Welbeing. Hutchins Center Working Paper 43, https://www.brookings.edu/wp-content/uploads/2018/o8/WP43-8.23.18.pdf.

Easterlin, R. A. (1974). Does economic growth improve the human lot? Some empirical evidence. In Nations and Households in Economic Growth: Essays in Honor of Moses Abramowitz, edited by Paul David and Melvin W. Reder. New York: Academic Press.

Evensky, J. M. (2011). dam Smith Adam Smith's Essentials: On T s Essentials: On Trust, F rust, Faith, and F aith, and Free Mark ee Markets. Syracuse University .

Federal Republic of Nigeria. (2008). National health bill. Available from: http://www.unicef.org/nigeria/ng publications_national_health_bill_20o8.pdf.

Fox, J. (2012). The Economics of Well-Being. Harvard University Review.

Frey, D., \& Stutzer, G. (2002). Happiness and Economics. Princeton. New Jersey: Princeton University Press.

Garver, R. (2020). Economic Damage From Civil Unrest May Persist for Decades. https://www.voanews.com/usa/nationturmoil-george-floyd-protests/economic-damage-civil-unrest-may-persist-decades.

Gottret, P., \& Schieber, G. (2016). Health Financing Revisited: A Practioner's Guide. Washington DC: The International Bank for Reconstruction and Development/The World Bank.

Katie, J. (2019). The Most Miserable Countries in the World. https://www.visualcapitalist.com/the-most-miserablecountries-in-the-world/.

Lagarde, M., \& Palmer, N. (2016). Evidence from Systematic Reviews to Inform Decision-Making Regarding Financing Mechanisms That Improve Access to Health Services for Poor People. A Policy Brief Prepared for the International Dialogue on Evidence-Informed Action to Achieve Health Goals in Developing Countries (IDEAHealth) in Khon Kaen. Thailand: Geneva: Alliance for Health Policy and systems Research.

Lerner, A. P. (1944). The economics of control. New York: Macmillan.

Lupton. (2011). Theoretical Perspectives on Medicine and Society. https://us.sagepub.com/sites/default/files/upmassets/46263_book_item_46263.pdf.

Lykken, D., \& Tellegen, A. (1996). Happiness is a stochastic phenomenon. Psychological Science, 7(3), 180-189.

Mansi, J., Gagan, D. S., \& Mandeep, M. (2019). Can I Sustain My Happiness? A Review, Critique and Research Agenda for Economics of Happiness. Sustainability, 11, 1-36.

Masiye, F., Kaonga, O., \& Kirigia, J. (2016). Does User Fee Removal policy provide financial protection from catastrophic health care payments? Evidence from Zambia. PLoS One, 11(1).

Nessen, R. (2008). The Brookings Institution's Arthur Okun - Father of the "Misery Index". https://www.brookings.edu/opinions/the-brookings-institutions-arthur-okun-father-of-the-misery-index/.

Nussbaum, M. C. (2005). Wellbeing, contracts and capabilities. In Manderson, L. (ed.) Rethinking Wellbeing. Perth: API Network. Australia Research Institute, Curtin University of Technology. 
Obi, O., \& Akubuo, C. (2018). Performance Evaluation of African Breadfruit (Treculia Africana) Seed Dehuller. Agricultural Engineering, 22, 51-60.

Odiji, O., Nwoke, O., \& Adeseke, A. (2016). The YouWiN Entrepreneurship Programme and National Development in Nigeria. International Journal of Economic Development Research and Investment,, 7(1), 8-15.

Ogunbekun, I., Adeyi, O., Wouters, A., \& Morrow, R. (2006). Costs and financing of improvements in the quality of maternal health services through the Bamako Initiative in Nigeria. Health Policy Plan, 11(3), 69-84.

Okonji, O. S., \& Igbanugo, C. I. (2019). Macroeconomic Performance and Economic Wellbeing in Nigeria: Evidence From Hanke's Misery Index. International Journal of Economics and Management Studies, 6(6), 7083.

Palmer, N., Mueller, D. H., Gilson, L., Mills, A., \& Haines, A. (2014). Health financing to promote access in low income settings - How much do we know? . Lancet [PUBMED], 364(13), 65-70.

Pareto, V. (1909). Manual of political economy. New York : Macmillan.

Rashad, A., \& Sharaf, M. (2015). Catastrophic Economic Consequences of Healthcare Payments: Effects on Poverty Estimates in Egypt, Jordan, and Palestine. Economies, 3(4), 216-234.

Reid, M. (2013). Nigeria still searching for the right formula. Bull World Health Organ, 86(66), 3-5.

Scitovsky, T. (1976). The Joyless Economy. New York: Oxford University Press .

Sen, A. (1993). Capability and wellbeing. In Nussbaum, M and Sen, A (Eds.) The Quality of Life. Oxford. Clarendon Press.

Soyibo, A., Olaniyan, O., \& Lawanson, A. O. (2009). National Health Accounts of Nigeria 2003-2005: Incorporating Sub-National Health Accounts of States. Ibadan: Main report submitted to Federal Ministry of Health. University of Ibadan.

Soyinbo, A. (2015). National Health Accounts of Nigeria 1999-2012. Final report submitted to World Health Organization. Ibadan: University of Ibadan.

Statista. (2020). Inflation rate in Nigeria 2021. https://www.statista.com/statistics/383132/inflation-rate-in-nigeria/.

Trending Economics. (2020). Nigeria GDP Growth Rate2010-2020 Data. https://tradingeconomics.com/nigeria/gdpgrowth.

Tule, K. M., Egbuna, E. N., Dada, E., \& Ebuh, G. U. (2017). A dynamic fragmentation of the misery index in Nigeria. Cogent Economics \& Finance, 5(1).

Veenhoven, R. (2004). Subjective measures of wellbeing. WIDER: Discussion Paper No. 2004/o7. United Nations University.

Welsch, H. (2007). Macroeconomics and life satisfaction: revisiting the "misery index". Journal of Applied Economics, 10(2), 237-251.

World Bank. (2015). Improving Primary Health Care Delivery in Nigeria Evidence from Four States. Working paper No 187. Washington DC: World Bank.

World Data Atlas. (2020). Current health expenditure as a share of GDP. https://knoema.com/atlas/Healthexpenditure-as-a-share-of-GDP.

World Health Organization. (2017). Country Cooperation Strategy: Federal Republic of Nigeria 2002-2007: World Health Organization Regional Office for Africa. Brazzaville: Available from: http://www.who.int/countries/nga/about/ccs_strategyo2_o7.pdf .

\section{Appendixes}

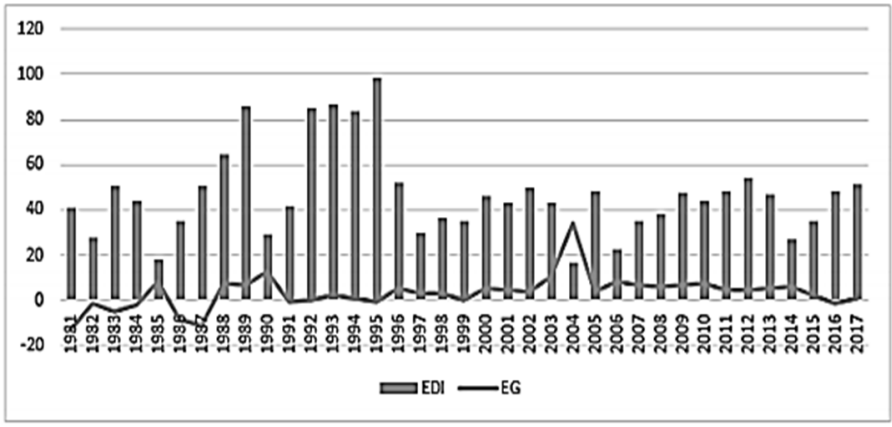




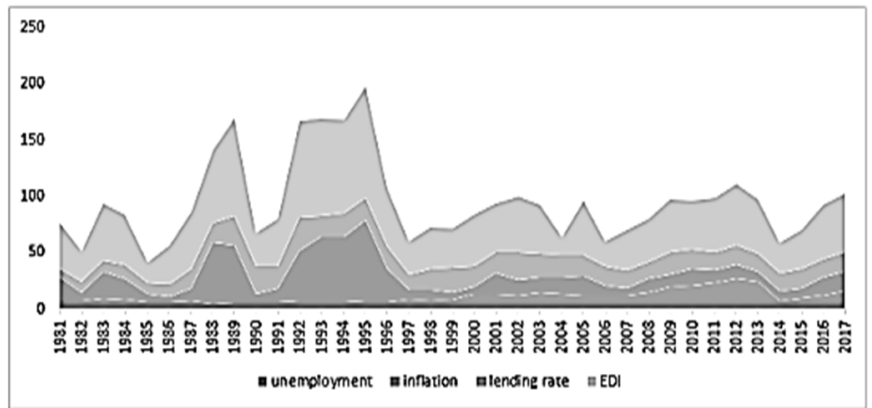

\begin{tabular}{llll}
\hline Years & Actual & Target & $\begin{array}{l}\text { Differential } \\
(\%)\end{array}$ \\
\hline 1990 & 3.6 & $\star \star *$ & \\
1995 & 51.6 & 15.00 & 243.94 \\
2000 & 14.5 & 9.0 & 61.41 \\
2005 & 11.6 & 10.0 & 15.65 \\
2010 & 11.8 & 11.2 & 5.36 \\
2011 & 10.3 & 12.0 & -14.31 \\
2012 & 12.0 & 9.5 & 26.12 \\
2013 & 7.96 & 9.87 & -19.38 \\
2014 & 7.98 & 7.50. & 6.38 \\
2015 & 9.55 & 8.00 & 19.38 \\
2016 & 18.55 & 11.90 & 55.88 \\
2017 & 15.37 & 10.71 & 43.53 \\
\hline
\end{tabular}

HEALTH EXPENDITURE AS A \% OF GDP
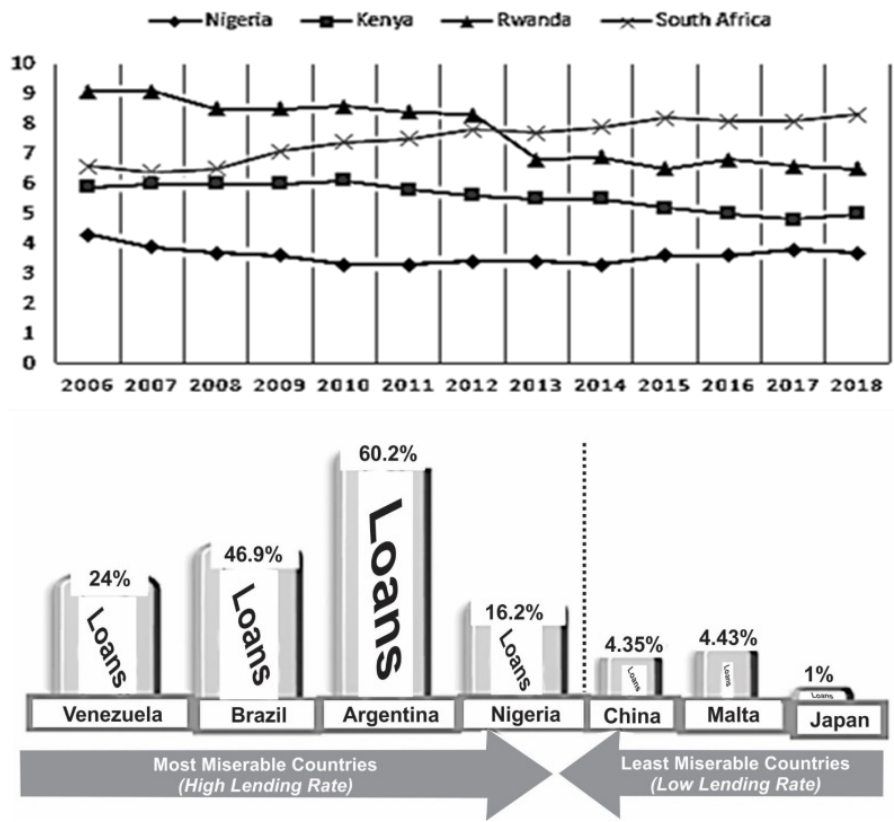